\title{
Morphoagronomic and molecular profiling of Capsicum spp from southwest Mato Grosso, Brazil
}

\author{
A.L. Campos ${ }^{1}$, T.N. Marostega ${ }^{1}$, N.S.S. Cabral ${ }^{1}$, K.L. Araújo ${ }^{1}$, M.E. Serafim ${ }^{2}$, \\ S. Seabra-Júnior ${ }^{1}$, C.P. Sudré ${ }^{3}$, R. Rodrigues ${ }^{3}$ and L.G. Neves ${ }^{1}$ \\ ${ }^{1}$ Departamento de Agronomia, Laboratório de Melhoramento de Plantas, \\ Universidade do Estado de Mato Grosso, Cáceres, MT, Brasil \\ ${ }^{2}$ Departamento de Engenharia Florestal, Laboratório de Solos, \\ Instituto Federal de Mato Grosso, Cáceres, MT, Brasil \\ ${ }^{3}$ Departamento de Agronomia, Laboratório de Melhoramento Genético Vegetal, \\ Universidade Estadual do Norte Fluminense, Campos dos Goytacazes, RJ, Brasil \\ Corresponding author: T.N. Marostega \\ E-mail: tamarostega@gmail.com \\ Genet. Mol. Res. 15 (3): gmr.15038167 \\ Received November 27, 2015 \\ Accepted January 22, 2016 \\ Published July 15, 2016 \\ DOI http://dx.doi.org/10.4238/gmr.15038167 \\ Copyright (C) 2016 The Authors. This is an open-access article distributed under the terms of \\ the Creative Commons Attribution ShareAlike (CC BY-SA) 4.0 License.
}

\begin{abstract}
The genus Capsicum ranks as the second most exported vegetable in Brazil, which is also considered to be a center of diversity for this genus. The aim of this study was to rescue genetic variability in the genus Capsicum in the southwest region of Mato Grosso, and to characterize and estimate the genetic diversity of accessions based on morphoagronomic descriptors and inter-simple sequence repeat molecular markers. Data were obtained following the criteria of the International Plant Genetic Resources Institute, renamed Bioversity International for Capsicum. Data were analyzed using different multivariate statistical techniques. An array of binary data was used to
\end{abstract}


analyze molecular data, and the arithmetic complement of the Jaccard index was used to estimate the genetic dissimilarity among accessions. Six well-defined groups were formed based on the morphological characterization. The most divergent accessions were 142 and 126 , with 125 and 126 being the most similar. The groups formed following agronomic characterization differed from those formed by morphological characterization, and there was a need to subdivide the groups for better distinction of accessions. Based on molecular analysis, accessions were divided into two groups, and there was also a need to subdivide the groups. Based on joint analysis (morphological + agronomic + molecular), six groups were formed with no duplicates. For all groups, the cophenetic correlation coefficient was higher than 0.8 . These results provide useful information for the better management of the work collection. All correlations between the combined distance matrix were significant by the Mantel test.

Key words: Pepper; Molecular analysis, ISSR; Multivariate analysis; Genetic variability; Brazil

\section{INTRODUCTION}

The genus Capsicum, which includes different varietal groups of peppers and chilies, has significant economic importance, and its fruits are used worldwide as fresh fruit, condiments, and spices. Their fruits also have ornamental/medicinal uses, lacrimogenic effects, and are an important source of vitamins A and C (Bosland and Yotava, 2000; Rêgo et al., 2012). The genus Capsicum is a member of the Solanoideae subfamily, which is believed to have its ancestral origins in the central tropical region of South America, in what is now Bolivia (Olmstead et al., 1999). Capsicum is important in defense against free radicals, and the consumption of these species can help in the prevention of chronic degenerative diseases, including cancer, cardiovascular disease, cataracts, and immune system dysfunction (Davis et al., 2007; Ogiso et al., 2008).

Currently, 38 species of Capsicum have been reported (USDA-ARS, 2011). The highest number of species (13) is concentrated in several regions of Brazil and the country is one of the largest centers of distribution of the genus, where representative forms of domesticated, semi-domesticated, and wild species can still be found (Rêgo et al., 2012).

In Brazil, peppers and chilies are grown by small farmers. The Capsicum production area is over 12,000 ha, of which 5000 ha contain peppers and the major producing States are Minas Gerais, São Paulo, Goiás, Ceará, and Rio de Janeiro. The annual yield is 75,000 ton/ha and productivity varies in the range of 10 -ton/ha on small farms with an area ranging from 0.5 to 10 ha (Ribeiro et al., 2007). The Capsicum market in Brazil involves more than US\$62.111 million per year, and the production of these species is growing. In 2008, Brazilian exports of Capsicum reached 9.22 tons, with a corresponding value of US\$14.582,608, positioning itself as the second most exported vegetable in Brazil (Reifschneider and Ribeiro, 2008).

For these reasons, plant genetic resources are considered a world heritage site of incalculable value, and their loss is an irreversible process, which affects global food security (Gomes, 2009). Therefore, the collection and conservation of plant genetic resources is of high importance.

Genetics and Molecular Research 15 (3): gmr.15038167 
Genetic diversity can be assessed simultaneously based on various characteristics, and the use of measurements and dissimilarity is recommended (Cruz and Carneiro, 2003). A convenient and efficient way of obtaining such measurements is through cluster analysis, which aims to group individuals such that there is maximum homogeneity within the group and maximum heterogeneity between groups (Johnson and Wichern, 1992; Cruz and Regazzi, 2001). The most widely used clustering methods are those involving optimization and hierarchical clustering (Cruz et al., 2011).

This study aimed to rescue genetic variability in the genus Capsicum in the Mato Grosso southwest region through the implementation of a Capsicum working collection, and thus, to ensure the preservation of these accessions for future use. In this study, the accessions collected were characterized based on morphoagronomic descriptors and inter-simple sequence repeat (ISSR) molecular markers, and the genetic diversity of the accessions studied was estimated.

\section{MATERIAL AND METHODS}

\section{Properties and morphoagronomic characterization of collections}

Units of the Capsicum collection have been identified and cataloged through visits to agricultural shops, business premises, and by identifying other Capsicum growers in the southwest region of the State of Mato Grosso, in the cities of Cáceres, São José dos Quatro Marcos, Curvelândia, and Mirassol d'Oeste, and nearby Bolivia (Corixa). A total of 21 Capsicum accessions were studied for morphological, agronomic, and molecular characterization. In turn, a joint analysis (morphological + agronomic + molecular) of these 21 accessions was performed. Seventy descriptors were used, consisting of 24 for the vegetative part, 41 for the inflorescence and fruit, and 5 for the seed. The accessions were characterized by specific morphoagronomic descriptors for Capsicum, as proposed by Bioverstity International (IPGRI, 1995).

The field experiment was conducted in the area of UNEMAT (State University of Mato Grosso), Cáceres - MT. The study environment is characterized, according to the Köppen classification, by a hot and humid tropical climate, with a dry winter. The average annual temperature of Cáceres is $26.24^{\circ} \mathrm{C}$. Here, the rainy season lasts for 4 months (December to March) and the dry season lasts for 8 months (April to November). The average annual water deficit is $400.30 \mathrm{~mm}$ and the water surplus is $147.03 \mathrm{~mm}$. The city of Cáceres is located in the southwest region of Mato Grosso, between the latitudes $15^{\circ} 27^{\prime}$ and $17^{\circ} 37^{\prime}$ south, and the longitudes $57^{\circ} 00^{\prime}$ and $58^{\circ} 48^{\prime}$ west, with an area of $24,398.399 \mathrm{~km}^{2}$ at an altitude of $118 \mathrm{~m}$ (Neves et al., 2011).

Seedlings were produced using protected cultivation and accessions were sowed in expanded polystyrene trays (128 cells) containing Plantmax ${ }^{\circledR}$ substrate. Plants were grown in a greenhouse and treatments were performed as recommended for the crop. One month from seedling emergence, the seedlings were planted in beds with spacing of $0.8 \mathrm{~m}$ between plants and $1.2 \mathrm{~m}$ between rows. The seedlings were placed in an experimental design of randomized blocks, with three replications, and three plants per plot. Cultural practices were performed and agricultural chemicals were applied as recommended for the crop. The drip irrigation system was adopted using auto-compensating drippers.

Genetics and Molecular Research 15 (3): gmr.15038167 


\section{Molecular characterization}

Molecular characterizations were performed in the Laboratory of Plant Breeding (LGMG)/Molecular Markers of the Universidade Estadual do Norte Fluminense Darcy Ribeiro, in Campos dos Goytacazes, RJ, Brazil.

Samples were prepared following the collection of young, healthy leaves in the active growth phase. Leaves from each accession were wrapped in aluminum foil, identified, and immediately plunged into liquid nitrogen to ensure that DNA was intact. Once in the laboratory, this material was macerated in liquid nitrogen to form a very fine powder.

About $100 \mathrm{mg}$ macerated tissue was transferred to $1.5-\mathrm{mL}$ tubes and immersed in liquid nitrogen for DNA extraction according to the protocol described by Sharma et al. (2008), with modifications as described below. Samples were placed in tubes and $1 \mathrm{~mL}$ preheated extraction buffer was added, containing 2\% CTAB; $2.0 \mathrm{mM} \mathrm{NaCl} ; 20 \mathrm{mM}$ EDTA; $100 \mathrm{mM}$ Tris-HCl, $\mathrm{pH} 8.0 ; 2 \% \mathrm{PVP}$; and $2.0 \%$ mercaptoethanol. The latter two components were needed to remove the phenolic compounds. Next, $5 \mu \mathrm{L}$ proteinase $\mathrm{K}(10 \mathrm{mg} / \mathrm{mL})$ was added to each sample. Samples were then incubated at $37^{\circ} \mathrm{C}$ for $30 \mathrm{~min}$, stirred gently every $10 \mathrm{~min}$, and incubated at $65^{\circ} \mathrm{C}$ for a further $30 \mathrm{~min}$. Then, the samples were centrifuged at $8000 \mathrm{~g}$ for $10 \mathrm{~min}$. The supernatant (about $800 \mu \mathrm{L}$ ) was transferred to a new tube and an equal volume of phenol:chloroform:isoamyl alcohol (25:24:1) was added for deproteinization. Samples were subjected to gentle inversions for 10 min until they became turbid. The organic phase was separated by centrifugation at $8000 \mathrm{~g}$ for $10 \mathrm{~min}$.

The supernatant was transferred to a new tube and $200 \mu \mathrm{L} \mathrm{NaCl} 2.0 \mathrm{M}$ containing $4 \%$ PEG was added to remove proteins and recover DNA; the samples were then incubated for 15 $\min$ at $4^{\circ} \mathrm{C}$. The material was centrifuged at $8000 \mathrm{~g}$ for $10 \mathrm{~min}$. Nucleic acids were precipitated by adding two-thirds $(400 \mu \mathrm{L})$ of the cold isopropanol volume, and incubating for $20 \mathrm{~min}$ at $-70^{\circ} \mathrm{C}$. The precipitate was sedimented by centrifugation at $8000 \mathrm{~g}$ for $10 \mathrm{~min}$. The supernatant was discarded and the precipitate was washed twice with $200 \mu \mathrm{L} 75 \%$ ethanol containing ammonium acetate to remove salts (between each wash, the material was centrifuged at 8000 $g$ for $5 \mathrm{~min}$ ).

DNA was quantified using a spectrophotometer (NanoDrop $\left.{ }^{\circledR}\right)$. Subsequently, the DNA was diluted $(5 \mathrm{ng} / \mathrm{mL})$ for use in polymerase chain reactions (PCR).

Amplification reactions were completed in a final volume of $19 \mu \mathrm{L}$ containing the following reagents: $10 \mathrm{mM}$ Tris- $\mathrm{HCl}, \mathrm{pH} 8.3 ; 50 \mathrm{mM} \mathrm{KCl} ; 2.4 \mathrm{mM} \mathrm{MgCl} ; 100 \mu \mathrm{M}$ each dNTP; $0.4 \mu \mathrm{M}$ primer oligonucleotides; $5 \mathrm{ng}$ genomic DNA; and $0.75 \mathrm{U}$ Taq DNA polymerase. A total of $2 \mu \mathrm{L}$ DNA was added to the rection mixture. PCR (GeneAmp PCR System 9700 Thermal cycler - Applied Biosystems) was conducted as follows: 3 min at $94^{\circ} \mathrm{C}$ for initial denaturation, followed by 40 cycles, each consisting of $94^{\circ} \mathrm{C}$ for $1 \mathrm{~min}, 40^{\circ}-55^{\circ} \mathrm{C}$ for $1 \mathrm{~min}$ (depending on the primer used), $72^{\circ} \mathrm{C}$ for $3 \mathrm{~min}$, and a final extension at $72^{\circ} \mathrm{C}$ for $7 \mathrm{~min}$. The amplified fragments were then separated on $1.5 \%$ agarose gel, stained with Gel Red, and subjected to UV light to visualize the results using a Photodocumentor Minibis Pro - BioImaging System). Gel images were captured for later analysis.

\section{Statistical analysis}

For analysis of the morphoagronomic data, the Genes software (Cruz, 2006) was used to obtain the dissimilarity matrix, and the R program (http://www.rproject.org) was

Genetics and Molecular Research 15 (3): gmr.15038167 
used to generate the dendrogram. Roots were grouped using the unweighted paired group method using arithmetic averages (UPGMA) and validation was provided by the cophenetic correlation coefficient.

To analyze molecular data, bands were visually assessed and the results were used to generate a matrix of binary data, which was subsequently used to calculate the dissimilarity matrix, wherein 1 corresponded to the presence of a band; 0 , to the absence of a band; and 2, when it was not possible to determine the presence of a band or when it was not possible to amplify a given accession using a particular primer.

\section{RESULTS}

\section{Collection}

The fruits of Capsicum spp collected from farms had different shapes, colors, and sizes; therefore, large morphological variability was observed and is shown in Table 1.

Table 1. Identification of Capsicum spp accessions, their collection numbers, common name, and origin (Cáceres, MT, 2014).

\begin{tabular}{|c|c|c|c|c|}
\hline Accession & Species & Common name & Origin & Locality \\
\hline 93 & C. chinense & Frying pepper & Prop. Roberto & MT \\
\hline 117 & C. chinense & Pepper & Prop. Antônio and Tereza & MT \\
\hline 119 & C. frutescens & Pepper & Prop. Antônio and Tereza & MT \\
\hline 120 & C. chinense & Pepper & Prop. Antônio and Tereza & MT \\
\hline 124 & C. Chinense & Smelling pepper & Prop. Ecio Sampaio & MT \\
\hline 125 & C. chinense & Red ('Goat') pepper & Prop. Esposa Cazuco & MT \\
\hline 126 & C. chinense & Pepper & Prop. Antonio Boger & MT \\
\hline 127 & C. chinense & Pepper & Prop. Antonio and Tereza & MT \\
\hline 129 & C. chinense & Brave pepper & Prop. Adonias Ribeiro & MT \\
\hline 132 & C. chinense & Smelling pepper & Prop. Antonio Boger & MT \\
\hline 133 & C. baccatum var. pendulum & Girl Finger pepper & Prop. Pedro Camargo & MT \\
\hline 135 & C. chinense & Malagueta pepper & Prop. Elcio S. Filho & MT \\
\hline 138 & C. baccatum var. pendulum & Girl Finger pepper & Prop. Elcio Sampaio Filho & MT \\
\hline 140 & C. chinense & Malagueta pepper & Prop. Roberto & MT \\
\hline 141 & C. chinense & Bird pepper & Prop. Maria Menezes & MT \\
\hline 142 & C. chinense & Smelling pepper & Prop. Antonio Boger & MT \\
\hline 144 & C. chinense & Yellow ('Foolish') pepper & Prop. Arlindo Brasdenut & MT \\
\hline 145 & C. chinense & Smelling pepper & Prop. Aparecido & MT \\
\hline 146 & C. baccatum var. pendulum & Chilean pepper & Prop. Maria Menezes & MT \\
\hline 151 & C. chinense & Sweet pepper & Prop. Valdemar G. & MT \\
\hline 152 & C. annuum var. glabriusculum & Capsicum Ireasunes red & & MT \\
\hline
\end{tabular}

Based on conversations with farmers, it was noted that, in all cases, the cultivated Capsicum accessions were provided by family members, or by neighboring farmers, representing the exchange of germplasm in this manner.

\section{Morphoagronomic characterization}

Twenty-one accessions were used to estimate genetic diversity based on the morphological descriptors of Capsicum. Variation was found for all studied characters and a weighted index was used for this analysis. A dendrogram was generated based on morphological descriptors (Figure 1), and a cut was performed at a distance of 0.31 , whereas a point of abrupt change provided the formation of five groups.

Genetics and Molecular Research 15 (3): gmr.15038167 


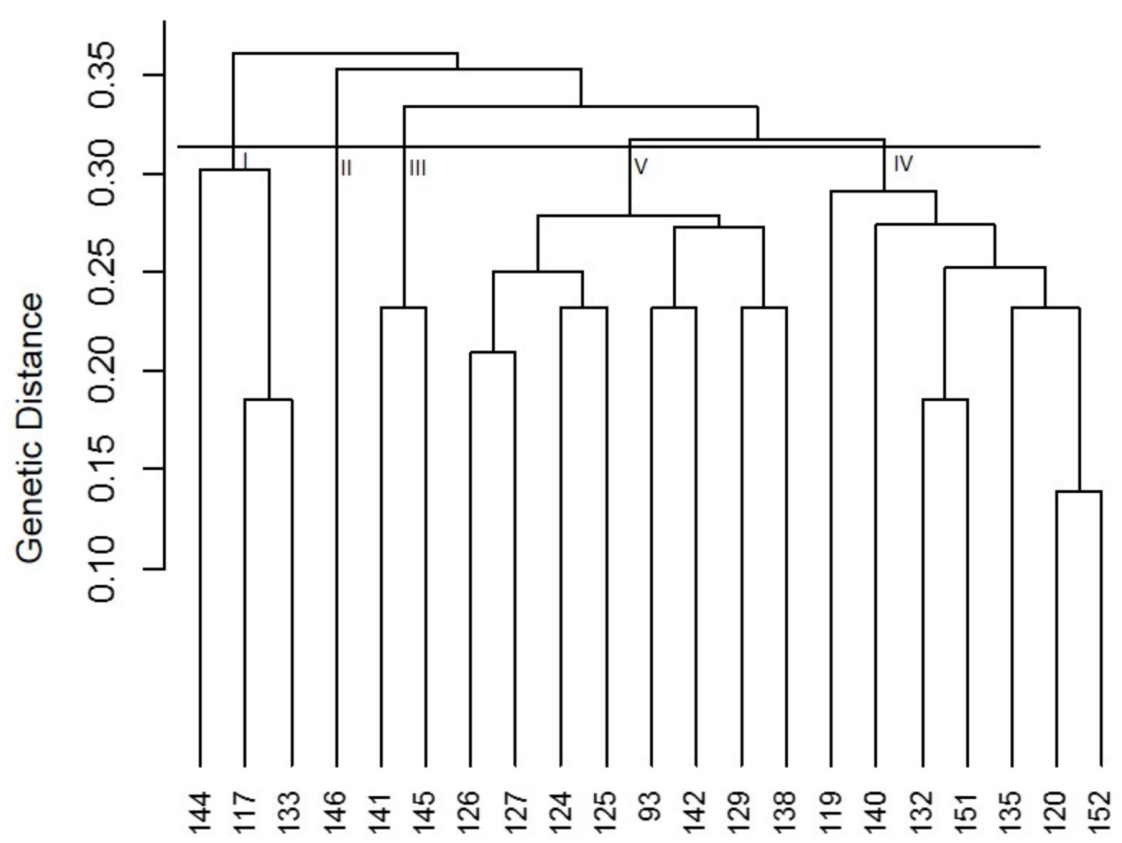

Figure 1. Dendrogram obtained by the unweighted pair group method with arithmetic (UPGMA) from the dissimilarity matrix expressed by the weighted index between 21 Capsicum accessions, by morphological descriptors. Cáceres, MT, 2013.

The data were grouped by the UPGMA method. The cophenetic correlation between data on the matrix of distance and grouping was 0.81 . Group I consists of three accessions, which are accessions 144,117 , and 133, and despite being from different species, this group is represented by broad leaves and large fruit. Group II consists of only one accession (accession 146), which belongs to the species C. baccatum var. pendulum, and was grouped alone owing to the presence of yellow-colored anthers, white-colored corolla, and small fruit. Group III consists of the accessions 141 and 145, which have small fruits, yellow coloration, and erect flower position. Group IV contained eight accessions (126, 127, 124, 125, 93, 142, 129, and 138), which possessed different characteristics such as leaf size, flower color, and fruit shape. Group V was characterized by the accessions 119, 140, 132, 151, 135, 120, and 152, which each bore red fruit.

The most divergent accessions are 142 and 126; however, there were from the same locality, and the absence of crossing was noted. In turn, accessions 125 and 126 are the most similar, even though they were obtained from distinct properties.

\section{Agronomic characterization}

The UPGMA method was used to analyze the agronomic data, and clustering is shown in the dendrogram in Figure 2. A cophenetic correlation of 0.82 was obtained, providing the formation of three groups, with a cut of 1.5 being used. 


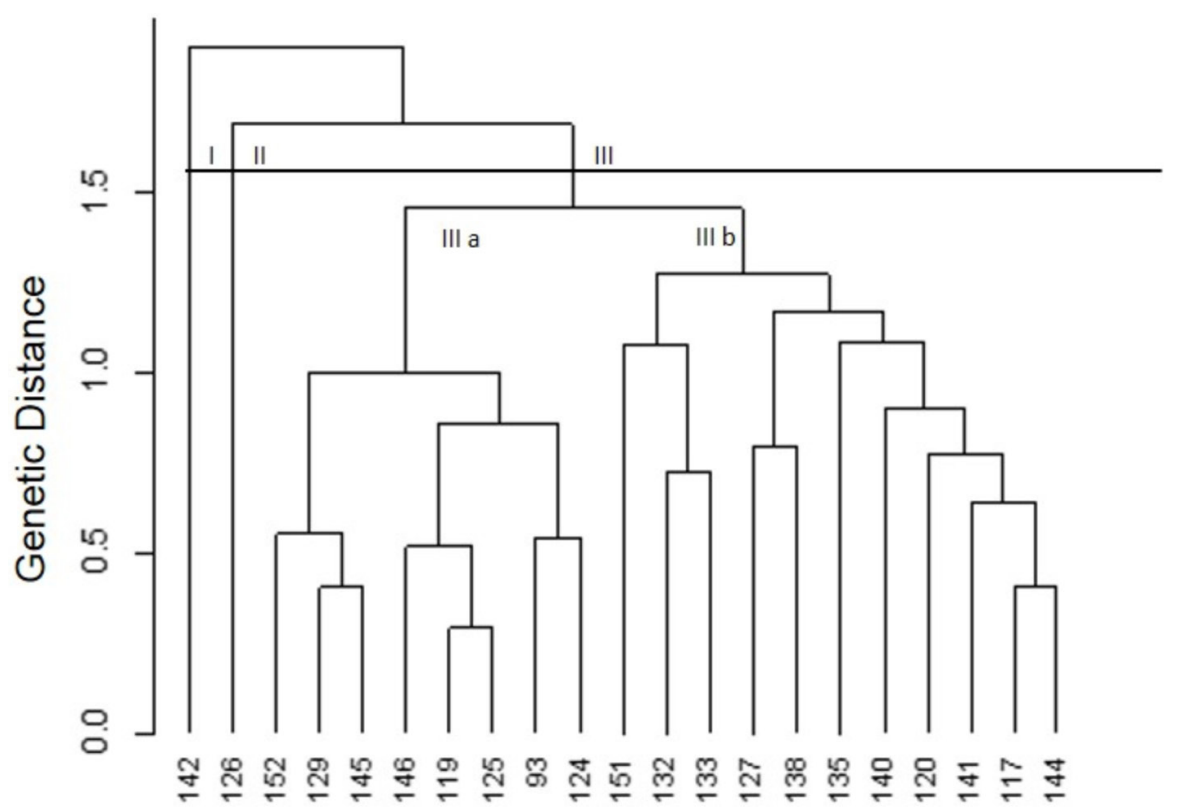

Figure 2. Dendrogram obtained by the UPGMA from the dissimilarity matrix expressed by the average weighted Euclidean distance between 21 Capsicum accessions, by agronomic descriptors. Cáceres, MT, 2013.

Group I consisted of one accession, which belongs to the species $C$. chinense. Accession 126 was allocated to Group II. The remaining 19 accessions were allocated to the third group, which accounted for approximately $93 \%$ of all accessions. Hence, it is difficult to analyze divergence between accessions because most of them formed a single group. Therefore, there was a need to cluster the third group into subgroups to better discriminate between accessions. In this way, accessions 152, 129, 145, 146, 119, 125, 93, and 124 make up subgroup III a, and subgroup III b contains the accessions 151, 132, 133, 127, 138, 135, $140,120,141,117$, and 144 .

\section{Molecular analysis}

Primers were selected and evaluated based on the number of bands generated and the polymorphism observed for these bands. The most polymorphic primer was UENF 43, which generated eight bands, followed by the primers UENF 07 and UENF 13, which generated six polymorphic bands each (Figure 3).

Based on the Jaccard index, the most distant genotypes were found to be 142 and 126, while accessions 125 and 126 were identified as the most similar.

A dendrogram based on data generated from the ISSR marker (Figure 4) was obtained, with a cut being made at a distance of 0.50 , taking into consideration the point of abrupt change, which resulted in the formation of two groups. This made it possible to discriminate between accessions. Similarly, accession 142 remained isolated in Group I, and the other accessions were placed in Group II. 

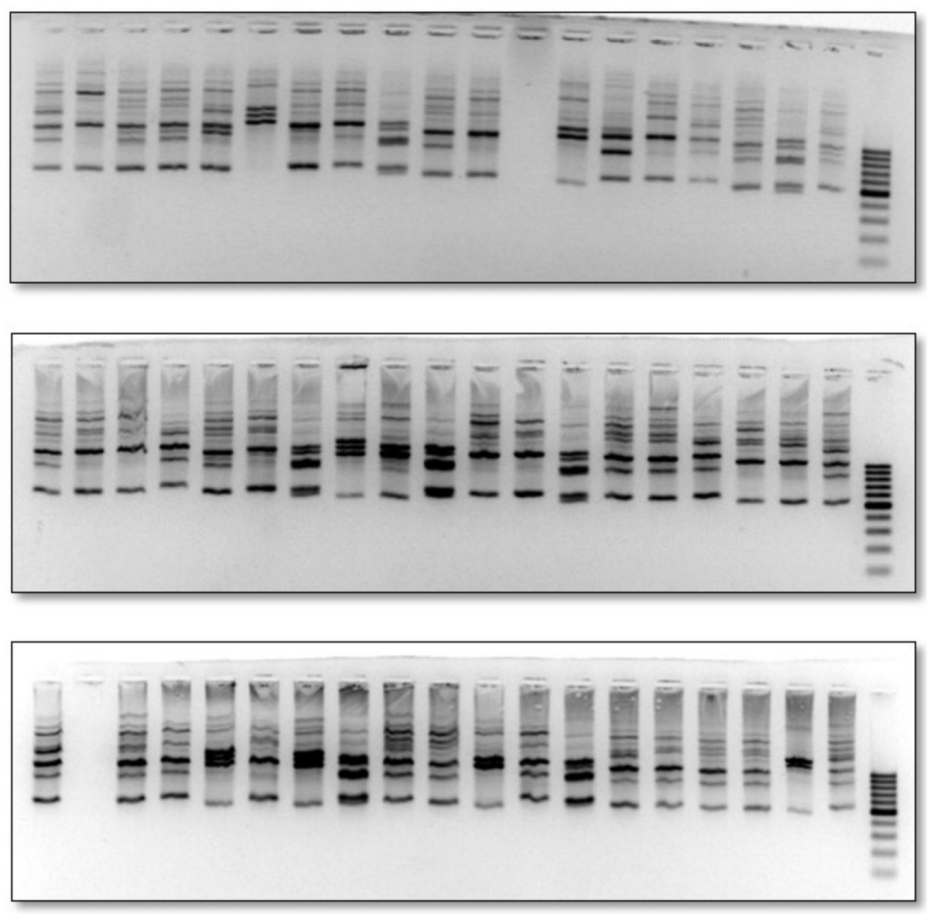

Figure 3. Profile of an ISSR (inter-simple sequence repeat) gel using the UENF 43 primer for 21 accessions of Capsicum spp. Cáceres, MT, 2013.

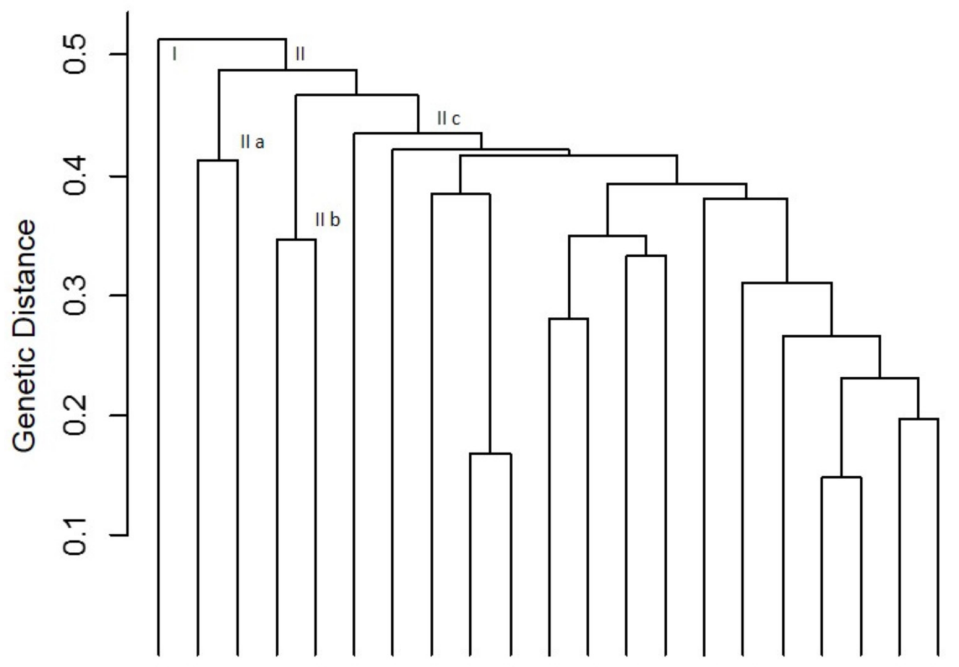

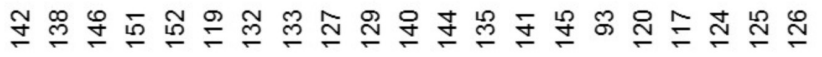

Figure 4. Dendrogram obtained by the UPGMA method from the dissimilarity matrix expressed by the arithmetic complement of Jaccard between 21 Capsicum accessions, by ISSR marker. Cáceres, MT, 2013. 
To improve analysis, the second group was divided into three subgroups. Subgroup II a was formed by accessions 138 and 146. Accessions 151 and 152, despite belonging to different species, were grouped in subgroup II b. A further subgroup (II c) containing 16 accessions was formed and included accessions 119, 132, 133, 127, 129, 140, 144, 93, 120 , $117,124,125$, and 126.

Accession 142 was found to separate from the others and was allocated to a specific group both for ISSR markers and for the agronomic descriptor, which demonstrates a good correlation between analyses.

All 17 molecular markers showed polymorphism. These data show that there was genetic diversity between accessions studied.

\section{Joint analysis}

A dendrogram was obtained based on the joint analysis of data generated by morphological, agronomic, and molecular traits (Figure 5), which revealed a cophenetic correlation coefficient of 0.81 .

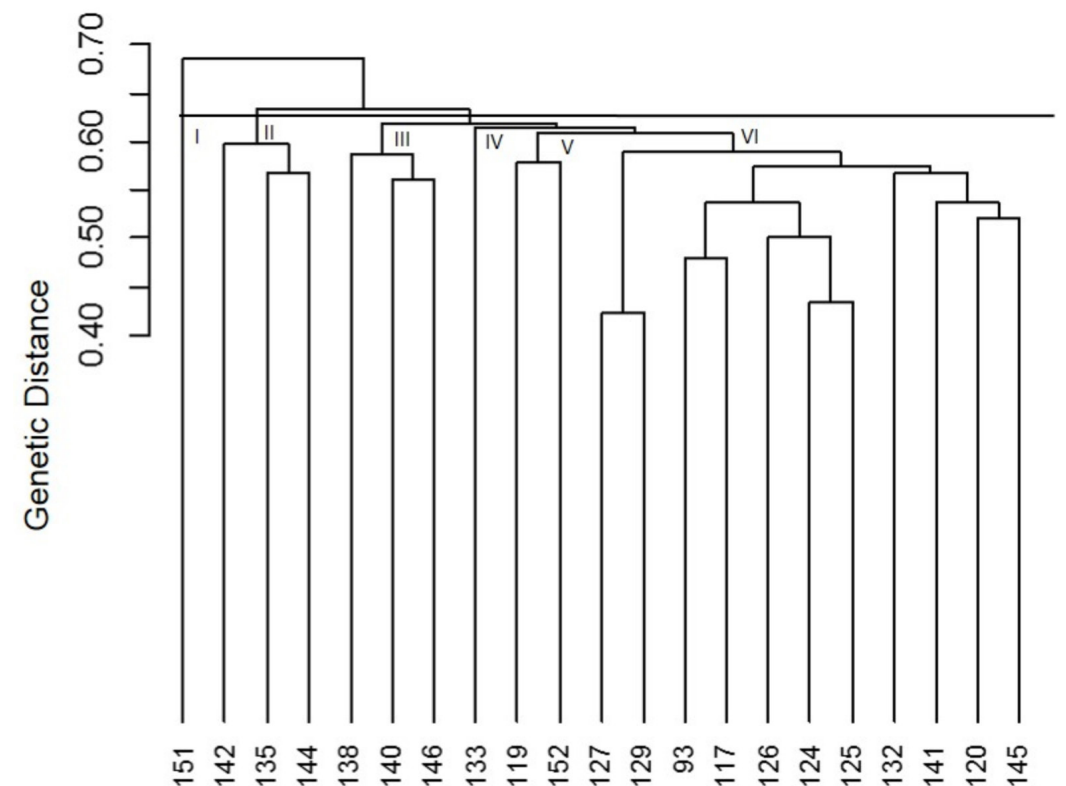

Figure 5. Dendrogram obtained by the UPGMA method from the dissimilarity matrix expressed by Gower distance, among 21 Capsicum accessions, by agronomic, morphological, and molecular descriptors. Cáceres, MT, 2013.

Considering a cut-off of 0.61 , six groups were formed. Group I consisted of one accession, which was 151. Accessions 142, 135, and 144 composed Group II. Group III contained the accessions 138, 140, and 146, and Group IV contained only accession 133. Group V contained accessions 119 and 152, and Group VI was formed by 11 accessions, which were 127, 129, 93, 117, 126, 124, 125, 132, 141, 120, and 145. 


\section{Comparison of matrices}

The four distance matrices were compared using the correlation of matrices (Mantel, 1967). The correlation values between matrices were as follows: joint with molecular, 0.81; joint with agronomic, 0.21 ; joint with morphological, 0.21 ; molecular with agronomic, 0.12 ; molecular with morphological, -0.04; agronomic with morphological, -0.02 (Table 2). All correlations between the combined distance matrix were significant by the Mantel test (1967). No other correlations were significant, highlighting the need to analyze genetic divergence by studying different types of characters.

Table 2. Correlation between matrices of joint distance.
\begin{tabular}{l|c|c|c|c}
\hline Matrices & Joint & Molecular & Agronomic & Morphological \\
\hline Joint & - & & & \\
\hline Molecular & $0.81^{* *}(++)$ & - & & \\
\hline Agronomic & $0.21^{* *}(++)$ & 0.12 & - & \\
\hline Morphological & $0.21^{* *}(++)$ & -0.04 & -0.02 & - \\
\hline
\end{tabular}

++ : Significant at $1 \%$ probability by the Mantel test based on 1000 simulations.

\section{DISCUSSION}

Using the Tocher and UPGMA methods of grouping when studying the genetic diversity among 23 accessions of cultivated Capsicum spp, Monteiro et al. (2010) reported that $C$. chinense was the most divergent of all groups, with the largest intragroup distances. This is consistent with the results obtained in the present study, which showed a high number of accessions in the same group.

Generally, fruit size and pungency descriptors were found to be the characteristics with the greatest variability; therefore, these can be considered important descriptors for the clustering of accessions, which contribute to the differentiation of groups. All traits studied contributed to the genetic dissimilarity of the accessions. Fruit size and flower color were important for the differentiation of groups, while the leave shape contributed the least to the observed divergence.

In a study on genetic dissimilarity among 17 accessions of Capsicum spp peppers, Neitzke et al. (2010) found similar results when verified the formation of four distinct groups by Tocher method for quantitative data of Capsicum spp.

The results of the present study show that considerable genetic diversity between the pepper hybrids studied could be detected by ISSR markers, which could be used for the conservation of genetic resources for new hybrids and crop breeding through assisted selection markers. The high variability of Capsicum accessions is maintained by farmers in the southwest region of Mato Grosso State. In the molecular characterization, the ISSR marker showed marked differences and polymorphism among the studied accessions, and no duplicates were detected.

For joint analysis, the value generated by the combination of traits (morphological, agronomic, and molecular) was greater than that found for the correlation between matrices generated individually. Thus, joint analysis of the data was more efficient at determining the genetic relationships among Capsicum accessions.

Corroborating the present findings, Vieira et al. (2007) obtained high Mantel

Genetics and Molecular Research 15 (3): gmr.15038167 
correlation values when studying 19 wheat genotypes and using data from molecular and quantitative morphological markers. Those authors observed moderate-to-high correlation between the matrices of the joint analysis (molecular and quantitative markers) and the quantitative and molecular arrays. Nonetheless, unlike this study, Silva et al. (2009) showed significant correlations only in the joint distance matrix, with the molecular array (0.55). Silva et al. (2009) also noted that when considering the association between morphological and molecular markers, the latter provides a much larger sample of the genome than analysis with morphological characters. Therefore, the ISSR marker makes it possible to evaluate different parts of the accession when evaluating the genetic diversity of Capsicum. According to Lefebvre et al. (2001) and Máric et al. (2004), the different number of morphological and molecular markers used also hinders the association. In all analyses, one can observe the absence of duplicates in the UNEMAT work collections, a result that allows the use of these materials in breeding programs of Capsicum.

The morphological and agronomic characterizations, as well as the molecular analysis through ISSR markers, were efficient to estimate the diversity and the genetic variability among the Capsicum spp accessions studied.

\section{Conflicts of interest}

The authors declare no conflict of interest.

\section{ACKNOWLEDGMENTS}

Research supported by CNPq and FAPEMAT.

\section{REFERENCES}

Bosland PW and Yotava EJ (2000). Peppers: Vegetables and Spice Capsicums. Crop Production Science in Horticulture. 1 ed. CAB International Publishing, Wallingford.

Cruz CD (2006). Programa Genes-Estatística experimental e matrizes. $1^{a}$ ed. Editora UFV, Viçosa.

Cruz CD and Regazzi AJ (2001). Modelos biométricos aplicados ao melhoramento genético. 2 ed. Editora UFV, Viçosa. Cruz CD and Carneiro PCS (2003). Modelos biométricos aplicados ao melhoramento genético. 1 ed. Editora UFV, Viçosa.

Cruz CD, Ferreira FM and Pessoni LA (2011). Biometria aplicada ao estudo da diversidade genética. 1 ed. Suprema, Visconde do Rio Branco.

Davis CB, Markey CE, Busch MA and Busch KW (2007). Determination of capsaicinoids in habanero peppers by chemometric analysis of UV spectral data. J. Agric. Food Chem. 55: 5925-5933. http://dx.doi.org/10.1021/jf070413k

Gomes LR (2009) Conservação in situ/on farm de recursos genéticos vegetais. In: Seminários em genética e melhoramento de plantas, 2009, Piracicaba.

IPGRI (International Plant Genetic Resources Institute) (1995). Descriptors for Capsicum (Capsicum spp.). International Plant Genetic Resources Institute, Rome.

Johnson RA and Wichern DW (1992). Applied Multivariate Statistical Analysis. 1 ed. Englewood Cliffs, New Jersey.

Lefebvre V, Goffinet B, Chauvet JC, Caromel B, et al. (2001). Evaluation of genetic distances between pepper inbred lines for cultivar protection purposes: comparison of AFLP, RAPD, and phenotypic data. Theor. Appl. Genet. 102: 741750. http://dx.doi.org/10.1007/s001220051705

Mantel N (1967). The detection of disease clustering and a generalized regression approach. Cancer Res. 27: 209-220.

Máric S, Bolaríc S, Martincic I, Pejic I, et al. (2004). Genetic diversity of hexaploid wheat cultivars estimated by RAPD markers, morphological traits and coefficients of parentage. Plant Breed. 123: 366-369. http://dx.doi.org/10.1111/ j.1439-0523.2004.00956.x

Monteiro ER, Bastos EM, Lopes ACA, Gomes RLF, et al. (2010). Diversidade genética entre acessos de espécies cultivadas de pimentas. Cienc. Rural 40: 288-283. http://dx.doi.org/10.1590/S0103-84782010005000015

Genetics and Molecular Research 15 (3): gmr.15038167 
Neitzke RS, Barbieri RL, Rodrigues WF, Corrêa IV, et al. (2010). Dissimilaridade genética entre acessos de pimenta com potencial ornamental. Hortic. Bras. 28: 47-53. http://dx.doi.org/10.1590/S0102-05362010000100009

Neves SMA, Nunes MCM and Neves NJ (2011). Caracterização das condições climáticas de Cáceres/ MT-Brasil, no período de 1971 a 2009: subsídio às atividades agropecuárias e turísticas municipais. Boletim Goiano de Geografia 31: 55-68.

Ogiso Y, Hosoda-Yabe R, Kawamoto Y, Kawamoto T, et al. (2008). An antioxidant of dried chili pepper maintained its activity through postharvest ripening for 18 months. Biosci. Biotechnol. Biochem. 72: 3297-3300. http://dx.doi. org/10.1271/bbb.80464

Olmstead RG, Sweere JA, Spangler RE, Bohs L, et al. (1999). Phylogeny and provisional classification of the Solanaceae based on chloroplast D 111-137. In: Solanaceae IV: Advances in Biology and Utilization (Nee M, Symon DE, Leseter RN, Jessope JP, eds.). Royal Botanic Gardens, Kew, UK, 1-110.

Rêgo ER, Finger FL and Rêgo MM (2012). Consumption of pepper in Brazil and its implicarions on nutrition and health of humans and animals. In: Peppers: Nutrition, Comsumpion and Health. Nova Science Publishers, New York, 159170.

Reifschneider FJB and Ribeiro CSC (2008). Cultivo de pimentas. In: Ribeiro CSC, Lopes CA, Carvalho SIC, Henz GM, Reifschneider FJB. (eds.), Pimentas Capsicum. Embrapa Hortaliças, Brasília, 11-14.

Ribeiro SFF, Carvalho AO, Da Cunha M, Rodrigues R, et al. (2007). Isolation and characterization of novel peptides from chilli pepper seeds: antimicrobial activities against pathogenic yeasts. Toxicon 50: 600-611. http://dx.doi. org/10.1016/j.toxicon.2007.05.005

Sharma K, Mishra AK and Misra RSA (2008). Simple and efficient method for extraction of genomic DNA from tropical tuber crops. Afr. J. Biotechnol. 7: 1018-1022.

Silva GO, Pereira AS, Souza VQ, Castro CM, et al. (2009). Distâncias genéticas entre genótipos de batata a partir de dados morfológicos, moleculares e genealógicos. Cienc. Agrar 30: 983-992.

USDA-ARS (United States Department of Agriculture - Agricultural Research Service) (2011). Grin species records of Capsicum. Beltsville.

Vieira EA, Carvalho FIF, Bertan I, Kopp MM, et al. (2007). Association between genetic distances in wheat (Triticum aestivum L.) as estimated by AFLP and morphological markers. Genet. Mol. Biol. 30: 392-399. http://dx.doi. org/10.1590/S1415-47572007000300016

Genetics and Molecular Research 15 (3): gmr.15038167 